\title{
Linking urban transport and land use in developing countries
}

\author{
Robert Cervero \\ University of California, Berkeley ${ }^{a}$
}

\begin{abstract}
The mobility challenges of the developing world are considerably different than those in wealthier, advanced countries, and so are the challenges of coordinating transportation and land use. Rapid population growth, poverty and income disparities, overcrowded urban cores, poorly designed road networks, spatial mismatches between housing and jobs, deteriorating environmental conditions, and economic losses from extreme traffic by congestion are among the more vexing challenges faced by developing cities that could be assuaged through improved coordination of transportation and urban development. This is underscored by examples reviewed in this paper from South Asia, Southeast Asia, China, India, Africa, and South America. It is concluded that whatever is done to improve transportation and land-use integration must be pro-poor. The cardinal features of integrated and sustainable transport and urbanism everywhere-accessible urban activities and safe, attractive walking and cycling environs - are particularly vital to the welfare and prosperity of urbanites in the world's poorest countries.
\end{abstract}

Keywords: Urban transportation; land use; Developing cities; Air quality; Poverty

\section{The challenges of rapid growth in developing cities}

The mobility challenges of the developing world are considerably different than in wealthier, advanced countries, and so are the challenges of coordinating transportation and land use. If the two are well coordinated, the potential benefits to natural environments, less-privileged members of society, and longterm economic prosperity, I argue, are even greater.

Smart growth and compact city development have gained wide policy interest in North America, Europe, and Australia over the past two decades. In truth, these parts of the world can do everything right in advancing sustainable futures; however, whatever progress they make in reducing greenhouse gas emissions (GHG) and fuel consumption will be quickly eclipsed if rapidly growing countries like India, China, and Brazil continue to mimic American-style patterns of suburbanization, car ownership, and travel.

The enormity of the urban planning challenges in developing countries is daunting. Last year, planet Earth became home to seven billion inhabitants, the majority of whom lived in cities. By 2030, United Nations projections call for as many as two billion additional city dwellers, making up 60 percent of the world's inhabitants. By 2050, urbanites are expected to

\footnotetext{
a robertc@berkeley.edu
}

make up 70 percent of total inhabitants (World Bank 2009). Ninety percent of this growth will be in the Global South.

Paralleling rapid population growth has been a proliferation of slums, widening income disparities, and evermounting demands for basic urban services including clean water and health care. Worldwide, the number of slumdwellers increased from 777 million in 2000 to 828 million in 2010 (United Nations Habitat 2011). Those living in SubSahara African cities suffer the most, with 62 percent of urban households residing in shantytowns and 64 percent of those with formal jobs living on less than US $\$ 1.25$ per day in 2010 (United Nations 2011). The combination of rapid growth and extreme poverty and deprivation poses unprecedented challenges: feeding, housing, clothing, educating, and transporting what is the equivalent of 10 new mega-cities of 10 million inhabitants each year for the next 20 years-that is, providing urban infrastructure and services for 10 "Jakartas" or "Lagos" annually. Projections show that the majority of new urbanites will live in cities and towns with fewer than 500,000 inhabitants (United Nations 2011). Smaller cities are at the develop-

\footnotetext{
${ }^{1}$ The Global South represents non-Nordic countries with mostly nontemperate climates, comprising countries south of continental Europe, the U.S., and Japan, excluding Australia and New Zealand. The term provides a geographic reference for developing countries, including those with low and lower-middle incomes as well as those that are rapidly industrializing and modernizing, such as in East Asia.
} 
ment stage where tremendous gains can be reaped from effectively coordinating transportation and urban development.

\section{Motorization trends}

The global count of motorized vehicles has been increasing at unprecedented rates. In 2010, there were nearly 1.2 billion passenger vehicles worldwide (United Nations Habitat 2011). Due mainly to higher personal incomes, developed regions of the world average far more motor vehicles (excluding two-wheelers) per 1000 people than developing ones (Figure 1). Car ownership in Vietnam, for example, was 13 per 1000 inhabitants in 2007 compared to over 800 per 1000 inhabitants in the U.S. (World Bank 2010). Adding motorized two-wheelers (mopeds, scooters, and motorcycles) to the mix, however, significantly changes these numbers. Vietnam had 125 motorized two-wheelers per 1000 inhabitants in 2007, more than six times its car population (World Bank 2011). Indeed, scooters, mopeds, and motorcycles make up much of the growth in motorized vehicles throughout Southeast Asia. For instance, in Laos and the Philippines, motorcycles comprise 78 and 43 percent of all traffic respectively (Chin 2011).

While car ownership rates in advanced economies are approaching saturation, motorization continues unabated in developing countries, fueled by economic growth and rising incomes. By 2050, the number of motor vehicles worldwide is projected to reach 2.6 billion-the majority of which will be found in developing countries, especially China, India and other Asian countries (United Nations Habitat 2011). China alone is projected to have some 800 million private automobiles by 2050, or around two-thirds of today's worldwide count. In some rapidly emerging economies like India, the number of cars, trucks, and motor scooters added to city streets each year is growing at more than 20 percent annually (Pan et al. 2011; Tiwari 2011). Mexico City's car population is increasing faster than its human population-two new cars enter into circulation every time a child is born (Jiron 2011). In India, private vehicle growth exceeds population gains by a factor of three (Jain 2011).

Most observers agree that rapid motorization is mostly driven by rising incomes (Ingram and Liu 1999; Sperling and Gordon 2009). From 2002 to 2007, China's per capita incomes almost doubled and car ownership nearly tripled (Kutzbach 2010). Societal values in China and elsewhere have also played a role, with owning a car often viewed as a rite of passage for those entering the middle class. Further spurring motorization are pro-car government policies. China's automobile manufacturing has been crowned a pillar industry, foisted by favorable tax policies and government incentives that encourage the purchase of automobiles and motorcycles. Today, China ranks first in worldwide automobile production (Organisation Internationale des Constructeurs d'Automobiles 2012). India has similarly embraced automobile manufacturing as a catalyst for economic growth, with low-cost subcompact cars such as the Tata Nano designed for and targeted at lower-income households. In much of Latin America and the Caribbean, reduced import tariffs and ease of credit have contributed to rising rates of car ownership (Jiron 2011).

Rapid motorization unavoidably shifts future travel from the most sustainable modes-public transport and nonmotorized ones (walking and cycling) - to private vehicles. Today, private vehicles make up around half of all urban trips worldwide (Pourbaix 2011). Daily trips in urban areas by private cars are projected to jump from 3.5 billion in 2005 to 6.2 billion in 2025, an 80 percent rise (Pourbaix 2011). Much of this growth will be in developing countries. If past trends continue, petroleum consumption and GHG emissions are projected to increase by 30 percent, matched by a similar growth in traffic fatalities. While they provide tremendous mobility benefits to those who cannot afford a car, motorcycles and scooters-which again are the dominant mode of transport in many Asian countries-come at a high cost. Besides congesting city streets, they can be exceedingly loud, contribute to traffic accidents, overtake sidewalks, and when powered by two-stroke engines, spew dirty tailpipe emissions. A poorly tuned two-stroke engine, for example, can emit 10 times as much hydrocarbons and particulate matter as a four-stroke engine or private car (Badami 1998; Cervero 2000; Gwilliam 2002).

Motorization is also marked by environmental justice concerns given the growing international trade of old secondhand vehicles from high-income to low-income countries. Over 80 percent of the vehicle stock in Peru was originally imported as used vehicles from the United States or Japan (Davis and Kahn 2011). In many African countries, import liberalization policies from the 1990s made it easier and cheaper for households to buy second-hand vehicles shipped across the Mediterranean Sea from Europe, flooding the market (and streets) in cities like Dakar and Lagos.

\section{Contrasting urban form contexts}

How do the spatial forms and land-use characteristics differ between cities in the developing versus the developed world? While there are certainly exceptions, for the most part, cities 


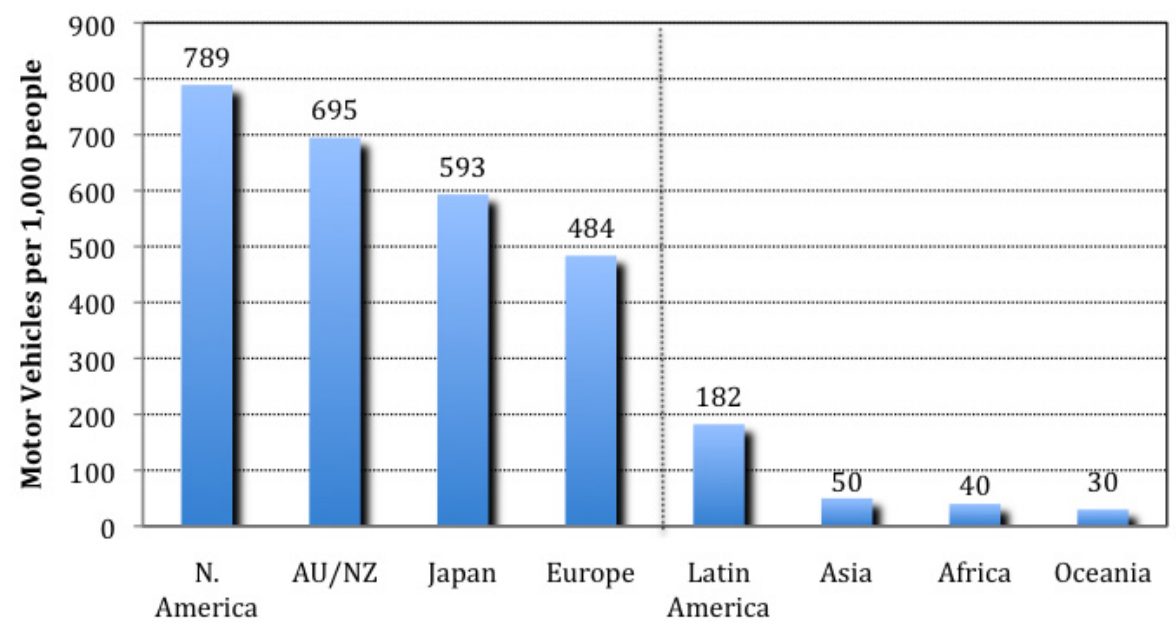

Developed Regions

Developing Regions

Figure 1: Comparison of 2009 motor vehicle ownership rates, developed versus developing regions. Source: World Bank, 2010

in the Global South can be distinguished from their Global North counterparts in terms of primacy, levels of monocentricity, population densities and trends, roadway designs, and geographic locations of the poor. This section discusses the contrasting built forms and their implications for travel.

\subsection{Primacy and monocentricity}

Developing countries tend to have more primacy, marked by a handful of the biggest cities being home to disproportionally large shares of nations' inhabitants as well as high-paying jobs. Concentration of national wealth in capital cities (e.g., Jakarta, Lagos, and Lima) also means concentrations of private assets and public infrastructure-e.g., automobiles, lanekilometers of motorways, and Internet bandwidth. It is the opportunity to secure wealth that draws poor, low-skilled, uneducated young men and women to primary cities in search of employment opportunities. Often they end up in the informal economy, which includes the operation of motorcycle taxis and unlicensed three-wheelers (Cervero 2000). In India, only about 100 of the more than 5,000 cities and towns have formal public transport (Jain 2011). Everything from handpushed rickshaws to private minibuses-operated by the poor for the poor-have stepped in to fill the gap.

Besides primacy, many developing cities have a more monocentric urban form than their developed-city counterparts. In many African and South American cities, for example, a third or more of formal jobs are concentrated in the urban core, considerably above what is found in most U.S. and European metropolitan areas (United Nations Habitat 2011).
Large concentrations of a nation's population, employment, and economic activities in primary capital cities, like Bangkok, Nairobi, and Mexico City, and in their urban cores, lead to exceedingly high traffic densities and comparatively long trips by motorized transport. Megacities of the developing world suffer from the worst congestion and airborne pollution anywhere (Gwilliam 2002; Suzuki et al. 2013). A recent study in 20 cities across six continents revealed that traffic congestion levels markedly worsened during the 2007 2010 period and particularly in fast-growing developing cities, despite being a period of global recession (IBM Corporation 2010). With a 24 percent annual growth rate in registered vehicles, traffic conditions deteriorated most rapidly in Beijing over this period. There, 69 percent of surveyed residents said traffic was so bad that they turned around and returned home at least once in the prior three years (IBM Corporation 2010). The growing popularity of helicopters is partly a response to the rising congestion problem in Latin American cities like São Paulo, Brazil and Mexico City, Mexico. In Santiago, Chile, the number of heliports jumped 67 percent, from 27 in 2003 to 45 in 2007 (Jiron 2011).

High primacy and monocentricity mean economies that accrue from concentration and agglomeration can quickly turn into diseconomies. While urban agglomerations yield economic benefits by allowing job specialization, efficient market transactions, and knowledge spillovers, if concentrated growth is not well planned-such as the integration of urban growth with metro investments-then over time such benefits erode. Agglomeration diseconomies, i.e., the disben- 
efit of too much or poorly planned concentrated growth, get expressed in the form of lost labor productivity from extreme traffic congestion, worsening air pollution that threatens public health, and an overall decline in the quality of urban living. Over-concentration of activities in the core has been blamed for Beijing's deteriorating traffic conditions and environmental woes Yang et al. (2012); Zhao (2011). The failure of distinct suburban clusters to form has undermined the ability to mount cost-effective, high-capacity transit services, leading to high car usage and vehicle kilometers travelled (VKT) per capita. Beijing's weak degree of multi-centered development likely stems in part from the tendency of its many ring roads to evenly spread development in all directions from the traditional core.

\subsection{Higher densities and more rapid decentralization}

Cities in developing countries are generally more than twice as dense as those in Europe and five-times as dense as in landrich developed countries like the U.S. and Australia. In 2000, they averaged 129 persons per hectare of built-up land area versus 50 and 25 in Europe and the U.S./Australia, respectively (Angel 2011). Within developing countries, urban densities vary considerably-densities in Asian and African cities are considerably higher than in Latin American cities. Among 1366 cities that made up 25 percent of the world's total population and half of its urban population during the 2000 to 2010 period, Asian and African cities were, on average, around 35 percent denser than cities in Latin America, 2 and a half times denser than European cities, and nearly 10 time denser than North American and Oceanic cities (mostly from the US, Australia, and New Zealand). Mean densities in Asian cities are skewed by several big, crowded cities-notably Dhaka, with nearly 35,000 inhabitants per $\mathrm{km}^{2}$, by far the world's densest city. The next densest cities are all in Asia: Mumbai; Macau, China; Surat, India; and Hong Kong. Of the world's 50 densest cities in the first decade of the 21 st century, 42 were in Asia.

Figure 2 reveals just how tightly packed Asian cities are by rank-ordering urban densities among the five densest cities (with populations of 500,000 or more) in six regions of the world (Asia, Africa, Latin America and the Caribbean, Europe, Oceania, and North America). The figure shows Asia's (and the world's) five densest cities are between 25 percent and 2100 percent as dense as others. After Asia, Latin American cities are generally the next densest, though again with a fair amount of variation. Colombian cities, led by Bogotá (with 20,531 people per $\mathrm{km}^{2}$ ), are Latin America's densest. European cities, notably those in Russia, generally come next in the ranking of densest cities. Cities in the US, Australia, and New Zealand average by far the lowest densities.

While developing cities have comparatively high densities, their density gradients have been flattening at a faster rate than in developed cities. Fuelled by rising incomes and motorization, developing cities are rapidly spreading outward. From 1990 to 2000, average urban densities fell from 3545 to 2835 people per $\mathrm{km}^{2}$ in developed countries compared to a drop from 9860 to 8050 people per $\mathrm{km}^{2}$ in developing ones (Angel et al. 2005). During the last decade of the 20th century, average built-up area densities declined in 75 of 88 cities in developing countries and in all 32 cities in developed countries that were surveyed by the World Bank (Angel 2011). The most rapid declines occurred in Asian cities, which not surprisingly are also most rapidly motorizing.

The link between rising wealth and decentralized growth is revealed in Figure 3. The figure shows changes in urban densities versus per capita GDP over the 1990-2000 period, with circle size denoting the change in population. Historically, developing cities averaged higher urban densities because vehicle ownership rates were low and people lived in tight quarters to be closer to everyday activities. But as incomes have risen, urban densities have declined in lockstep, mimicking the sprawling settlement patterns of developed cities.

More than rising wealth is spawning sprawl in developing cities. In Greater Cairo and Mexico City, sprawl is fueled mostly by informal housing settlements while on the outskirts of Mumbai and Delhi, new towns and employment subcenters have been the largest consumers of once exurban land (Bertaud 2011; United Nations Habitat 2011). Social exclusion, class segregation, and poverty itself can also stretch city boundaries-e.g., barrios and favelas (i.e., shantytowns and informal settlements) mark the peripheries of most Latin American cities as places of last resort. Sprawl in China is partly induced by local government policy wherein municipalities buy agriculture land at low prices, add infrastructure and services, and then lease to developers at much higher priceseffectively practicing value capture as a revenue generating tool (Gakenheimer and Yang 2006). In emerging economies like China, India, and Brazil, land speculation is further fueling sprawl as developers build outward to serve the burgeoning population of middle-income households and expansion needs of an enlarged corporate sector. In India, zoning policies that suppress permissible densities as a means of decongesting central cities have been blamed for inducing sprawl in recent decades (Bertaud 2011; Suzuki et al. 2013). Easy-toobtain credit for low-income housing has triggered an explosive growth in low-cost but isolated residential enclaves on the 


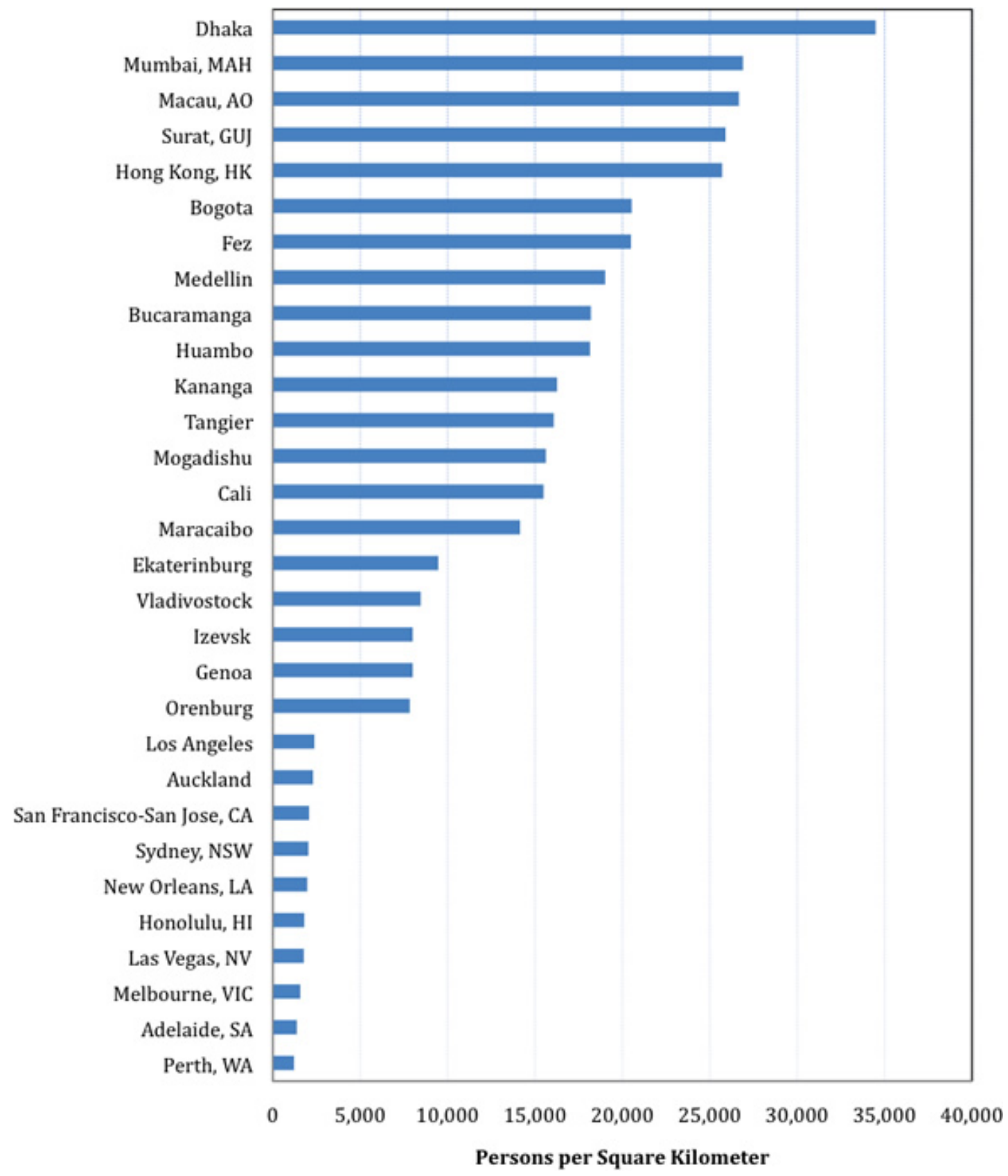

Figure 2: Urban population densities among the five densest cities of 500,000 inhabitants or more in six global regions, 2000 to 2010 period. Global regions: Asia, Africa, Latin America and Caribbean, Europe, Oceania, and North America. Source: UN-Habitat database, calculated by author. 


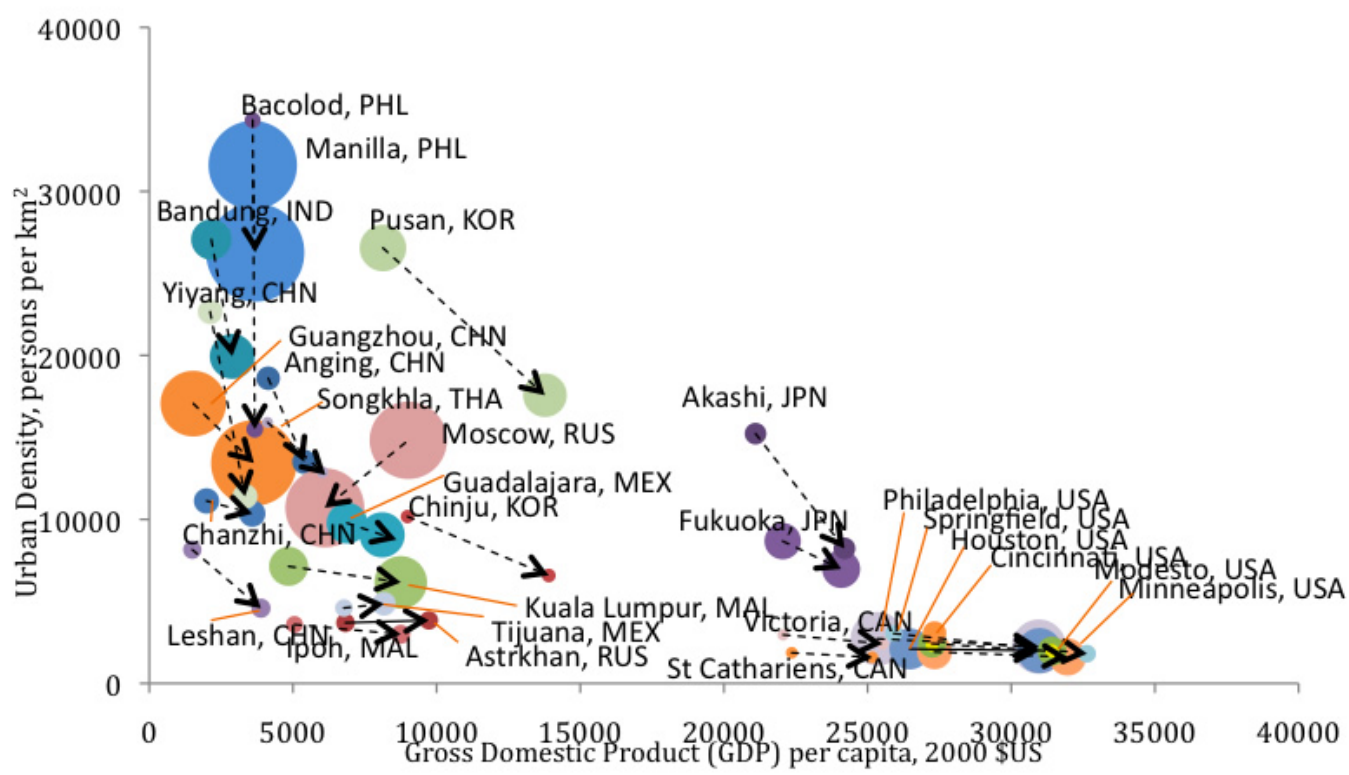

Figure 3: Changes in urban densities and GDP per capita, 1990 to 2000, among global cities. Data adapted from Angel et al., 2005. Source: Leaver, Samuelson, and Leaver, 2013.

outskirts of many Mexican cities, which over time has lead to abandonments; from 2006 to 2009, 26 percent of such housing that was built was unoccupied (Infonavit 2011). Nearly a third of individuals who abandoned their homes did so because of poor access to jobs, schools, and family.

\subsection{Sparse road densities and poor road hierarchies}

Another notable difference in the built environments of the Global South is their comparatively undeveloped road infrastructure. Less than 10 percent of land area is devoted to roads in many cities of Africa, South Asia, and Southeast Asia (e.g., Nairobi, Kolkata, and Jakarta). This contrasts with 15 to 20 percent in many rapidly emerging economies (e.g., Seoul and São Paulo), 20 to 25 percent in much of continental Europe (e.g., London and Paris), and 35 percent or more in America's largest automobile-oriented cities (e.g., Houston and Atlanta) (Figure 4). In India, the annual growth rate in traffic during the 1990s was around 5 percent in Mumbai, 7 percent in Chennai, and 10 percent in Delhi. However none of these cities expanded their road supply by even 1 percent annually over this period (Pucher et al. 2005).

It is not just lack of road capacity that harangues many third-world cities but also a lack of a rational road hierarchy that allows for efficient traffic flows from local streets to distributor-collectors to main arterials. For instance, Nairobi, a city of some 4 million inhabitants, has few collector streets and major thoroughfares relative to similar-size developed cities. The city's arterials are mostly radial and the lack of circumferential roads force-funnels many peripheral trips through the central business district with widespread effects on traffic flows. Dar es Salaam suffers the effects of a monocentric metropolis without any circumferential highways to divert through traffic. The city's main commercial district, largest retail market, main hospital, industrial zone, and port are all close to the center, resulting in extreme traffic convergence (and thus congestion) during peak hours. Central Bangkok has a fishbone street pattern, featuring narrow local streets (called sois) that channel most motorized trips onto oversaturated thoroughfares. Bangkok's absence of road hierarchy-notably distributor roads-has spawned an informal network of motorcycle taxis that have become the de facto distributor systems in most informal settlements (Cervero 1991).

The trade-off between road space, urban form, transit provisions, and transit usage is revealed by experiences in large Indian cities. Table 1 shows that 21 percent of Delhi's total land area is devoted to roads, compared to 11 percent in Mumbai and 5 percent in Kolkata (both which lie on a peninsula and thus have restricted geographies). Almost 80 percent of all trips in Kolkata are by some form of public transport compared to 60 percent in Mumbai and 42 percent in Delhi. Kolkata and Mumbai have extensive suburban 
railways and Kolkata also has a 16.5 kilometer underground metro. Delhi relies on more flexible and atomized forms of "mass transportation"- auto rickshaws, motorcycle taxis, and pedicabs-to serve the multi-directional, less lineally focused travel patterns. In India, therefore, few roads and restricted geographies translate into high ridership in high-capacity vehicles. More roads and spread-out development, as in Delhi, however, mean less transit use and smaller-scale services.

\subsection{Spatial mismatches}

The social geographies of developing cities also tend to be much different than developed ones. Notably, spatial mismatches in where the poor and needy live and where the formal jobs with livable wages are located are more pronounced. In the U.S., the poor often live in older districts just outside the urban core whereas many of the jobs they qualify for are on the periphery. In most of the developing world, the opposite holds: the poor live mainly on the far-flung fringes, isolated from job opportunities that are mostly in the urban core. They effectively trade off comparatively high travel costs (in both time and money) for cheap (and illegal) housing costs, the opposite of what traditional residential location theory, framed from a first-world perspective, holds (Alonso 1964).

Spatial mismatches impose extreme financial burdens on the poor, especially in mega-cities. In the poor informal housing settlements on the outskirts of Mexico City, beyond the service jurisdiction of the city's 201-kilometer metro, residents sometimes must take two to three separate collectivos (sharedride taxis and microbuses) to reach a metro terminal that provides low-cost connections to the core city and job opportunities (Cervero 1998, 2000). Travel can consume 25 percent or more of daily wages (Kaltheier 2002; Vasconcellos 2001)). Time costs can also be exorbitant: 20 percent of workers in Mexico City spend more than three hours traveling to and from work each day (World Bank 2009). Studies show that taking a series of informal minibuses and motorized tricycles to and from work can cost 20 to 25 percent of daily wages in rapidly growing cities like Delhi, Buenos Aires, and Manila and as high as 30 percent in Nairobi, Pretoria (South Africa) and Dar es Salaam (Carruthers et al. 2005; Ferrarazzo and Arauz 2000; Kaltheier 2002). For the very poor of the developing world, whatever savings that accrue from illegally squatting and living in squalor (e.g., lack of piped water or indoor plumbing) often evaporate from the high expenses incurred in reaching income-earning opportunities in the city as well as essential medical, educational, and retail destinations.

Research reveals the mobility impacts of imbalanced growth. A study of commuting in Beijing found that those liv- ing in residential neighborhoods that are "job poor" are more than twice as likely to commute by private car than those living in areas with a balance of jobs and housing (Zhao 2011). Huge travel time expenditures have also accompanied imbalanced growth in Dakar, Senegal. There, shortages of affordable housing have forced many workers to live in Thies, which is two hours away during peak period (Godard 2011). Most commute by minibus or by shared taxi or even by hitchhiking. Women must often endure the hardships of spatial isolation since many cannot afford paratransit and are bound to remain close to home to raise children and carry out household chores. Spatial mismatches between where the poor reside and economic opportunities lie in many Sub-Saharan African cities prevent many from breaking out of the shackles of poverty, owing to restricted access to not only job destinations but also information networks about opportunities for training services and microloans.

\section{The economic drag of worsening traffic congestion}

The combination of rapid motorization, rising incomes, urban sprawl, undeveloped road systems, and spatial mismatches have given rise to the world's worst traffic conditions in cities of the developing world. Time losses from traffic congestion are estimated to comprise 2 percent of GDP in Europe and 2 to 5 percent in Asia (European Commission 2011). The hidden external costs of traffic congestion in Metro Manila, Dakar, and Abidjan have been pegged at nearly 5 percent of those cities' GDPs (Chin 2011; UITP (International Association of Public Transport) 2011). Such costs not only exact a burden on the present generation but also commit future generations to long-term debts, which can eventually slow economic growth.

Besides undeveloped street networks, poor traffic management contributes to hellish traffic conditions in many developing cities. The spillover of street hawkers and other vendors of the informal economy onto overcrowded streets-along with the concentration of informal markets near major intersections and bus depots-creates bottlenecks. In Sub-Saharan Africa, street vendors occupy around one-third of road space in crowded cities (Pendakur 2005; Pirie 2011). Traffic management is also usually woefully absent. Cambodia's Phnom Penh, a city of 2 million inhabitants, has 864 kilometers of roads but just 36 traffic signals (Chin 2011).

Freight movements also contribute to traffic tie-ups throughout the Global South. In most poor countries, the goods-movement sector lacks basic infrastructure, such as 
Table 1: Urban form, roads, and public transport in Indian cities

\begin{tabular}{|l|l|l|l|}
\hline & Kolkata & Mumbai & Delhi \\
\hline Urban Form & Linear & Linear & Spread-Out \\
\hline Density (persons per km $\left.{ }^{2}\right)(2010)$ & 19,367 & 26,898 & 14,110 \\
\hline Percentage Land Area to Roads (2000) & $5 \%$ & $11 \%$ & $21 \%$ \\
\hline Percentage Mechanized Trips using Transit (2000) & $78 \%$ & $60 \%$ & $42 \%$ \\
\hline Transit Types & $\begin{array}{l}\text { Surface Railway / } \\
\text { Metro }\end{array}$ & Surface Railway & $\begin{array}{l}\text { More auto-rickshaws } \\
/ \text { motorcycle-taxis / } \\
\text { Metro }\end{array}$ \\
\hline
\end{tabular}

Adapted from data in Pucher et al., 2005.

freight terminals, warehousing, parking and staging areas, freight-forwarding centers, and other logistical needs. Few developing cities plan for freight movements, thus a haphazard, dysfunctional arrangement of urban logistics is often the norm. In Lome, the capital city of Togo in West Africa, the absence of a bypass road around the city funnels trucks leaving the port directly into the core of the city. Heavy trucks contribute to and suffer from poor-quality roads because wear and tear exponentially rises with the dead-axle weight of a vehicle (e.g., one heavily loaded truck can inflict as much road damage as 10,000 passing cars) (Papagiannakis and Masad 2011). In turn, rutted streets slow trucks more than lighter vehicles.

There, too, is a social dimension to traffic congestion, with the poor suffering the most. In the developing world, buses, which cater mostly to carless, low-income individuals, are most vulnerable to the speed-eroding effects of traffic congestion. Because many are long, lumbering vehicles with slow acceleration and deceleration, restricted turning radii, and limited maneuverability to switch lanes, buses move the slowest in highly congested conditions. Average peak-period bus speeds in Bangkok are 11 kilometers per hour, for example, compared to 20 kilometers per hour in Curitiba, Brazil, one of the first cities to provide exclusive bus lanes (Cervero 1998; Vasconcellos 2001). Stop-and-go traffic causes buses to overheat and breakdown. Unreliable services, in turn, chase away choice consumers who have the option of driving a car instead.

\section{Impacts of transport investments on urban form}

Because of extreme congestion and generally poorer levels of regional accessibility, investments in new road and transit infrastructure could be expected to exert stronger influences on urban form and land-use patterns in developing than devel- oped cities. This likely holds even more for public transport where in megacities like São Paulo, studies show, only around one- third as many urban activities can be reached by metrorail or bus during the evening peak hour as by private car (Casiroli 2009).

As in the developed world, new infrastructure in developing cities has generally been a force toward decentralization, marked by a flattening of the density gradient. Due to the absence of strong regional planning, critics contend that new metrorail systems in Mexico City and Santiago have induced sprawl even more than in developed cities (Figueroa 1990; Gwilliam 2002). Metrorail investments in these and other Latin American cities have also contributed to the segregation of households by income and class, displacing many poor to the metropolitan periphery while modernizing and opening the inner city to wealthier segments of the population. Critics charge such maldistributive impacts are rooted in transportation investments that favor the mobility interests of wealthier individuals and a lack of compensatory programs, like affordable housing requirements, to moderate such displacements (Vasconcellos 2001). A more balanced portfolio of transportation improvements that ensures benefits accrue to all socio-economic groups can mitigate such unintended consequences. The desire to better serve the mobility needs of the poor partly explains Bogotás pro-active investments in world-class bus rapid transit (BRT) and bikeway networks over the past decade (Cervero 2005; Peñalosa 2002).

\subsection{Bus rapid transit and urban development}

BRT will no doubt play an increasingly prominent role in the global campaign to achieve more sustainable urban and mobility futures. This is partly because the bulk of future population growth will be in intermediate-size cities, the very places where BRT is often more cost-effective than its pricier alternative, metrorail transit. Future growth of not only population 
but also economic outputs is also projected for intermediatesize cities (Joshi-Ghani and Glaeser 2013).

BRT systems are being built at a rapid-fire pace throughout the developing world, thanks to their lower investment costs in comparison to metrorail systems and their relatively short construction periods. Currently, BRT investments are found in more than 160 cities worldwide and at least as many cities are at various stages of contemplating, planning, designing, or investing in new systems. Worldwide, BRT systems span a broad spectrum of design and service types, from "BRT lite" with minimal features (e.g., partially dedicated lanes and wider station spacings) to high-end exclusive-lane and fullservice operations that offer speed advantages similar to those of metrorail systems. Latin American cities like Curitiba, Bogotá, São Paulo, and Santiago led the way in building high-end BRT in the early 2000s. China, which has been adding BRT lane-kilometers at a faster pace than anywhere over the past eight years, is similarly building high-end systems, such as in the cities of Guangzhou and Xiamen.

Empirical evidence on BRT's city-shaping impacts is limited, in developed and developing countries. Experiences in Ottawa and Curitiba suggest that when governments proactively leverage development through supportive zoning, targeted infrastructure investments, and introducing other progrowth incentives, BRT has spawned TOD (Cervero 1998; Levinson et al. 2002). Rent capitalization and conversion to higher-density development has been attributed to BRT investments in Seoul, South Korea (Cervero and Kang 2011). Appreciable land-value benefits have also been reported for Bogotá TransMilenio BRT (Munoz-Raskin 2010; Rodríguez and Mojica 2009; Rodríguez and Targa 2004). Controlling for unit and neighborhood characteristics, Rodríguez and Targa (2004) found multifamily housing rents increased from 6.8 percent to 9.3 percent for every five-minute reduction in walking time to a TransMilenio station. Follow-up work revealed that creating pedestrian-friendly environments near BRT bus stops have further increased property-value benefits (Estupiñán and Rodríguez 2008).

\subsection{Experiences in Bogotá}

While Bogotás TransMilenio is a substantial, widely celebrated BRT investment, able to carry some 45,000 passengers per direction per hour, reshaping urban form and landuse patterns was not a primary objective in its design. Building the system quickly and enhancing affordable transport for the poor was. Placement of BRT lines in mostly economically stagnant zones that were largely built out has suppressed land development and so has the siting of BRT stations in busy roadway medians, which limits joint development opportunities and creates unattractive pedestrian environs around stations. Minimal proactive station-area planning and a dearth of incentives for the owners of private property to redevelop parcels have also tempered TOD activities.

Between 2004 and 2010, the mean floor-area ratio (FAR) of residential and commercial development increased by 7 percent throughout the city of Bogotá versus 5 percent within 1000 meters of stations along the initial 42-kilometer system (Suzuki et al. 2013). In fact, more densification occurred along surface bus routes that feed into suburban TransMilineo stations than around BRT stops. Matched pair comparisons of changes in building footprints between 1998 and 2011 for a one-kilometer radii around BRT stations and otherwise similar control areas further revealed weak effects on urban growth. For all but end-of-line stations, more new construction occurred beyond than within 1000 meters of stations. Other researchers have similarly found more land-use densification near TransMilenio's terminal stations than control areas (Bocarejo et al. 2013). In contrast, studies of landuse changes of rail systems in the U.S. reveal terminal stations, typically surrounded by large surface parking lots and bus-interchange facilities, experience few land-use changes (Cervero and Landis 1997; Huang 1996). In Bogotá, the higher degree of station-area activities has been largely due to commercial opportunities at terminals, representing busy transfer points between feeder buses and trunk-line BRT services.

Findings from Bogotá square with earlier assessments of transit investments and urban development (Cervero and Landis 1997; Cervero and Seskin 1995; Knight and Trygg 1977), namely that transit cannot overcome weak local real estate markets. Station siting also matters. Placing stops in the medians of active roadways inevitably means a poor-quality pedestrian-access environment and thus little commercial development near the stations themselves. TransMilenio's design gave little weight to the pedestrian experience. The visually prominent skywalks that connect to BRT stops create lengthy, circuitous walks, can be noisy (resonating like steel drums during peak traffic conditions, by some accounts), and are difficult for the elderly, disabled, and semi-ambulatory individuals to negotiate. Bogotás experiences further show that planning matters. Neither the city nor neighborhood districts (where detailed land use planning is regulated and implemented) prepared station-area plans to orchestrate private development, change zoning (including increasing permissible densities), introduce complementary improvements (like 
streetscape enhancements) to entice private investments, or take any other proactive steps to leverage new development.

\subsection{Experiences in Ahmedabad}

In 2009, Ahmedabad opened India's first and what today remains the country's largest BRT network. Called Janmarg (People's Way), the current 45-kilometer system was built to relieve mounting traffic congestion in India's fifth largest city. With some 5.5 million inhabitants, Ahmedabad is today one of the world's fastest growing cities (Kotkin 2010). The ingredients are thus there for BRT to shape future urban growth: rapid growth and motorization coupled with worsening traffic congestion. To date, however, few notable changes have occurred near Janmarg stations.

As in Bogotá, Janmarg was envisaged and designed as a mobility investment, not a city-shaping one. Janmarg lines were and are being selected to serve the city's fastest growing areas, more so than in the case of Bogotá; however, little attention has been given to the physical integration of BRT stops with surrounding neighborhoods or increasing the share of future populations and workers near BRT. Janmarg, slated to span some 220 kilometers at build-out (Figure 4), which would make it one of the most extensive BRT systems anywhere, was designed mainly to keep costs low. Little thought was given to urban development possibilities. So far, no land-use or TOD plans have been prepared for any Janmarg stations. What land development is occurring has been left solely to private market forces.

So far, Ahmedabad officials have opted to maintain uniform densities throughout the city, regardless of how close parcels might be to transit corridors. This has been done to disperse trips and thus decongest the city. It has also been done for socio-cultural reasons, namely to avoid creating a privileged class of land owners whose new-found wealth is created through government fiat. However, keeping densities uniform also shifts growth to the periphery, in a more autooriented configuration. In the near term, the city could experience less traffic congestion due to density caps; however, over the long term, the resulting auto-oriented urban form could backfire, creating more traffic congestion and air pollution for the region as a whole.

Several design shortcomings also need to be overcome if Ahmedabad is to spawn TOD. Janmarg was and is being designed as a closed system, requiring users to access stations sited in the medians of roadways by foot, bicycle, car, twowheeler, three-wheeler, or surface-street buses. Little attention, however, has been given to perpendicular connectors to BRT stops. No secondary feeder systems provide safe and effi- cient pedestrian, bikeway, and transit connections to mainline services. While a substantial network of cycletracks was built in conjunction with Janmarg, for the most part bike paths run parallel rather than perpendicular to the busway, thus functioning more as competitive than complementary systems. Moreover, there is no bicycle parking at stations. What few pedestrian-ways exist near Janmarg stops are often occupied by motorcycles and fast-moving three-wheel vehicles.

\subsection{BRT and urbanism in Curitiba}

A counterpoint to failures in coordinating BRT and urban development is the well-chronicled experiences of Curitiba, Brazil. Guided by a cogent long-term vision of the future city, the municipal government mandated that all mediumand large-scale urban development be sited along a BRT corridor. Orchestrating regional growth has been the Institute for Research and Urban Planning (IPPUC), an independent entity charged with ensuring integration of all elements of urban growth.

A design element used to enhance transit accessibility in Curitiba is the "trinary" - three parallel roadways with compatible land uses and building heights that taper with distance from the BRT corridor. The first two floors of the busway, which do not count against permissible plot ratios (building height/land area), are slated for retail uses. Above the second floor, buildings must be set back at least five meters from the property line, to allow sun to cast on the transitway. The inclusion of upper-level housing entitles property owners to density bonuses, which has led to vertical mixing of uses within buildings. An important benefit of mixed land uses and transit service levels along these corridors, in addition to extraordinarily high ridership rates, has been balanced by bidirectional flows, ensuring efficient use of bus capacity. The higher densities produced by the trinary design have translated directly into higher ridership. Concentrated commercial development has also channeled trips from residences beyond BRT terminuses to the trinary corridors. In 2009, for example, 78.4 percent of trips boarding at the terminus of Curitiba's north-south trinary corridor were destined to a bus stop on the same corridor (Duarte and Ultramari 2012). Today, Curitiba's share of motorized trips by transit ( 45 percent) is the highest in Latin America (Santos 2011). High transit use has appreciably shrunk the city's environmental footprint. Curitiba's annual congestion cost per capita of $\$ 0.67$ (in US\$2008) is a fraction of São Paulo's (Suzuki et al. 2010). The city also boasts the cleanest air of any Brazilian city with more than 1 million inhabitants, despite having a sizable industrial sector. The strong, workable nexus that exists between Curitiba's 


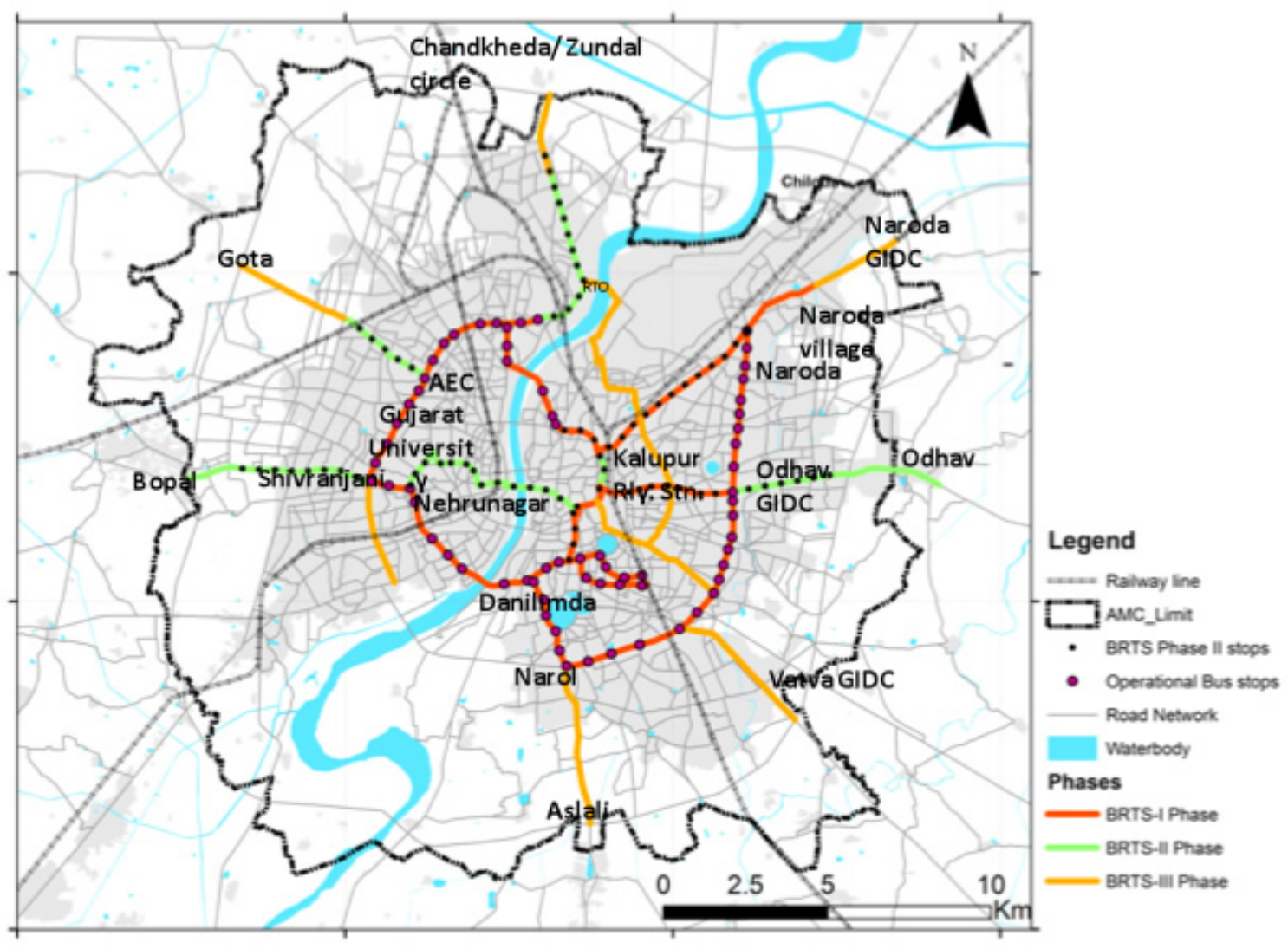

Figure 4: Ahmedabad's Janmarg BRT sytems: phases I (completed), II (currently under construction), and III (planned). Source: CEPT University, Ahmedabad. 
bus-based transit system and its mixed-use linear settlement pattern deserves most of the credit.

Sustained political commitment has been pivotal to $\mathrm{Cu}-$ ritiba's success. The harmonization of transit and land use took place over 40 years of political continuity, marked by a progression of forward-looking, like-minded mayors who built on the work of their predecessors. A well-articulated long-term vision and the presence of a politically insulated regional planning organization, the IPUCC, to implement the vision have been crucial in allowing the city to chart a sustainable urban pathway.

One area where Curitiba's BRT investment has fallen short is the provision of housing for the poor. Most social housing built in the last 40 years for Curitiba's poor has been far from main transit axes and transport corridors (Duarte and Ultramari 2012). The availability of cheaper land and laxer environmental regulations on floodplain development prompted $\mathrm{Cu}$ ritiba's authorities to put the most disadvantaged households in the least transit-accessible locations.

\section{Land use and travel}

The 5 Ds-density, diversity, design, distance to transit, and destination accessibility-have gained currency for examining how built environments shape travel in the U.S. (Ewing and Cervero 2010). Far less is known on this subject in developing parts of the world, though new evidence is steadily accumulating. Besides averaging higher densities, developing cities often have a richer diversity of land uses and a more walkable urban fabric than their first-world counterparts. Lax or non-existent land-use regulations have given rise to an organic pattern of mixed land-use in many developing cities.

Because average incomes and car ownership levels are lower, built environments might be expected to hold stronger sway over travel decisions in the Global South. In Santiago, higher urban densities and closer proximity to metrorail stations have been associated with lower per capita levels of vehicle kilometers traveled ((Zegras 2004); (Zegras 2010)). More recent research found higher population densities also reduce the likelihood of Santiago households owning a car (Zegras 2012). Being close to a subway station further reduced car ownership rates; however, land-use diversity had minimal influences. A travel-diary study of 1500 Bogotá residents found that density and land-use diversity had little influence on the amount of time spent walking and cycling whereas design attributes of neighborhoods, like street connectivity and sidewalk provisions, did (Cervero et al. 2009). Going from a Bogotá neighborhood with low levels of road connectivity (measured by the ratio of links to intersections) to high levels, increased the likelihood that residents walked 30 minutes or more per day by 220 percent (Cervero et al. 2009). Many of Bogotás older neighborhoods evolved during the pre-automobile era, which unencumbered by strictly enforced zoning rules has resulted in urban neighborhoods that exhibit similar densities, mixes of land use, and access to transit. What does vary is quality of walking environment, which in Bogotás case influences nonmotorized travel (Cervero et al. 2009; Estupiñán and Rodríguez 2008; Rodríguez et al. 2009). Studies in Taipei and Hong Kong have similarly found street designs to more strongly affect walking than factors like high densities and mixed land uses (which are commonplace in both cities) (Lin and Yang 2009; Zhang 2004).

Walking quality has important age and gender dimensions. In Teheran, a recent study found highly walkable neighborhoods to be most conducive to the elderly walking more often (Li 2003). Environments designed with more street lighting and a mixture of land uses that generate foot traffic many hours of the day and days of the week are likely to decrease the risk of violence to women (Meleis 2011). Well-designed streetscapes with destinations close by tend to draw city residents of all backgrounds to sidewalks and public spaces, creating the kind of natural surveillance and 'eyes on the street' championed by Jacobs (1961). Bogotás proactive investment in walkways, plazas, and sidewalks close by and connected to the Transmilenio BRT system has been credited with enhancing public safety and enlivening pedestrian environments, which in turn has encouraged households to upgrade their homes and neighborhoods (Tarazona 2008).

Perhaps it is because pedestrian-friendly environments are in such short supply in developing cities that when they do exist, they are found to strongly influence how people travel (Cervero et al. (2009); Suzuki et al. (2010)). Expanded, improved, and better-connected pathways are sometimes important features of slum upgrading programs. In La Vega Barrio, one of Caracas, Venezuela's largest and oldest informal settlements, 30 pathways that crisscross steep hillsides have been built or rehabilitated to enhance access to jobs, schools, and medical clinics, all part of a major neighborhood upgrading initiative (World Economic Forum 2012). Design features like smaller city blocks can also encourage foot travel in developing cities. In Ahmedabad, only 13 percent of trips made by those living in a neighborhoods with an average block size of 4 hectares, were by foot, compared to 36 percent for an otherwise similar neighborhood with much smaller average block sizes of 1.2 hectares (Swamy et al. 2012). 
Experiences from China reveal how changes in built environments fundamentally change travel in rapidly growing settings. Paralleling China's shift to a market economy have been dramatic transformations of urban environments-from a traditional high-density, pedestrian- and cyclist-oriented urban form to an increasingly spread-out, auto-oriented one (Pan et al. 2009). Before 1978, state danwei (work units) provided housing to virtually all employees, and since most urbanites worked for a state-owned enterprise, virtually all Chinese city dwellers lived in danwei housing or other publicly provided housing (Day and Cervero 2010). In 1985, only around 10 percent of the housing stock in large Chinese cities was privately held (Li 2003). With housing usually sited near workplaces, large Chinese cities evolved during much of the 20th century with a compact, mixed-use form. With the liberalization of land markets in the 1990s came the displacement of many working class households to the periphery-often, to isolated superblock development enveloped by wide streets (Li and Siu 2001). The change from organically evolved, mixed-use enclaves-where many people lived, worked, and shopped in the same area-to car-oriented large-block suburbs dramatically enlarged households' travel footprints. A study of 900 households that either voluntarily moved or were relocated from Shanghai's urban core to isolated, superblock, and gated housing units on the periphery showed that travel patterns were strongly affected. Dramatic shifts from nonmotorized to motorized travel and journeys of far longer duration resulted in an estimated 50-percent increase in surveyed households' VKT (Cervero and Day 2008). Another study found that Shanghai residents living in higher-density areas with smaller blocks and denser street networks averaged around one-half the car ownership levels as those living in more car-oriented, superblock districts (Pan et al. 2009). Residents of pedestrian/cycle-friendly neighborhoods, moreover, travelled shorter distances than those of other neighborhoods, even for trips made by the same mode.

\section{Institutional challenges}

The best ideas for advancing sustainable urbanism and mobility in fast-growing parts of the world will go nowhere unless there is the political will and institutional capacity to embrace and move forward with them. The ability to manage and respond to escalating demands for urban travel is often limited in developing cities. Institutional shortcomings-such as an insufficiently trained and educated civil-service talent pool or absence of a transparent and corruption-free procurement process for providing transport infrastructure-abound.
Limited experience with urban management, budgeting and accounting, urban planning, finance, and project supervision have thwarted Indonesia's decentralization of infrastructure programs from the central to local governments over the past decade.

Institutional fragmentation undermines the ability to coordinate urban services, within and across sectors, in developing cities (Dimitriou 2011). Separating urban sector functions into different organizations, each with its own boards, staff, budgets, and bylaws, often translates into uni-sectoral actions and missed opportunities, such as the failure to site new housing projects near BRT stations. Bloated bureaucracies are notorious for introducing waste and delays in the deployment of urban transport projects.

In rapidly urbanizing cities, transportation departments are more often preoccupied with responding to everyday crises than strategically planning to prevent them from occurring in the first place. Strategic planning and coordination of landuse and transportation and across different transport modes is practically non-existent. Institutions rarely have sufficient time or funds to expand transport infrastructure fast enough to accommodate the meteoric growth in travel. Most operate constantly in the catch-up mode. The ability to advance sustainable transport programs or introduce efficient pricing schemes presumes something that rarely exists-a wellmanaged transport authority that sets clear and measurable objectives and rigorously appraises the expenditure of funds in a transparent and accountable way.

Despite these impediments, progress is being made. The city of Bangkok recently announced a paradigm shift in planning that emphasizes redesigning the city to eliminate or shorten trips, to create complete streets, and to make the city more livable. The Amman, Jordan master plan of 2008 promotes high-density, mixed-use development through the identification of growth centers, intensification along select corridors across the city and the provision of safe and efficient public transportation. Similar transit-oriented master plans have been prepared for Islamabad, Delhi, Kuala Lumpur, and Johannesburg in recent years. Mexico City has aggressively invested in BRT and bicycle infrastructure to promote a culture of and built form conducive to sustainable mobility. As in the developed world, officials in these and other places increasingly realize that integrated transport and land-use planning is critical toward not only a greener urban future but also to being economically competitive on the global stage.

Integrated planning development must also be supported at national levels (Gakenheimer 2011). India's national urban transport policy of 2006 embraces integrated transport and 
land-use planning as its number-one priority. Half the cost of preparing integrated transport and land-use plans in Indian cities is covered by the central government. For the past 25 years, Brazil has had a national urban transport policy that supports planning for sustainable transport and urban growth in BRT-served cities like Curitiba and Belo Horizonte.

\section{Close}

Integrated transport and land-use planning needs to be elevated in importance in developing cities before it is too late. As more and more growth shifts to cities of the Global South, opportunities for linking land development and transport infrastructure should not be squandered. While motorization rates are subsiding in developed countries, they are growing exponentially elsewhere. Given that a large share of future urban growth is projected for small-to-medium size cities, busbased forms of smaller-scale transit-oriented development interlaced by high-quality infrastructure for pedestrians and cyclists holds promise in many global settings. Many developing cities have the kinds of prerequisites needed if railway and BRT investments are to trigger meaningful land-use changes, including rapid growth, rising real incomes, and increased motorization and congestion levels. This, of course, assumes there is supportive planning and zoning, public-sector leveraging and risk sharing, a commitment to travel demand management to remove many built-in incentives to car use, and the capacity to manage the land-use shifts that are put into motion by transportation infrastructure investments.

While integrated transport and land development can relieve congestion, cleanse the air, and conserve energy, its potential to reduce what remains the gravest problem facing the Global South-extreme and persistent poverty-is every bit if not more important. All that is done in the developing world must pass the litmus test of helping to alleviate poverty. Designing cities and transport systems to enhance accessibility and affordability is pro-poor and so are initiatives that strengthen non-motorized and public transport, keep fares affordable, and protect vulnerable populations from the hazards of motorized travel. Mass transit needs to be pro-poor across the board. In many developing countries, this means investing in busways over metros to keep fares affordable and targeting affordable housing to transit-served corridors. In Brazil, transit is kept affordable via national legislation called Vale Transport that requires employers to provide bus passes for commuting expenses that exceed 6 percent of workers' earnings. In Cairo and Bogotá, tens of thousands of low-income households have been relocated to more transit-accessible sites.
Being pro-poor also means designing high-quality and safe walking and cycling environments. Walking is often the only form of transport for the very poor. Many are "captive walkers," who cannot afford an alternative. In African cities, a third of all trips are by walking and in places like Dakar and Douala, the share is much higher, over 60 percent (UITP (International Association of Public Transport) 2011). Mixed land-use patterns and walking/cycling friendly environments allow the very poor to allocate income for other urgent purposes and thus helps reduce poverty. In the very poorest cities, small interventions, e.g., siting basic services such as schools, health centers, markets, and water standpipes to reduce travel distances, can make a big difference in the amount of time and energy devoted to transport. The time freed up allows women to achieve gainful employment and children to attend schools. The cardinal features of integrated and sustainable transport and urbanism everywhere-accessible urban activities and safe, attractive walking and cycling environs-are particularly vital to the welfare of the neediest members of the world's poorest countries. 


\section{References}

Alonso, W. 1964. Location and land use. Cambridge, MA: Harvard University Press.

Angel, S. 2011. Making room for a planet of cities. Cambridge, MA: Lincoln Institute of Land Policy.

Angel, S., S. Sheppard, and D. Civco. 2005. The dynamics of global urban expansion. Washington, DC: The World Bank, Transport and Urban Development Department.

Badami, M. 1998. Improving air quality in Delhi. Habitat Debate, 4(2):22-23.

Bertaud, A. 2011. Mumbai FAE/FSI conundrum: The perfect storm. URL http://alain-bertaud.com/AB_Files/AB_ Mumbai_FSI_Conundrum_Revised_sept_2011.pdf.

Bocarejo, J. P., I. Portilla, and M. A. Pérez. 2013. Impact of TransMilenio on density, land use, and land value in bogotá. Research in Transportation Economics, 40(1):78-86. ISSN 0739-8859. doi: 10.1016/j.retrec.2012.06.030. $<$ ce:title>Urban Transport in Developing Countries: CODATU Special Issue</ce:title>, URL http://www.sciencedirect.com/science/article/pii/ S0739885912001023.

Carruthers, R., M. Dick, and A. Saurkar. 2005. Affordability of public transport in developing countries (Transport Paper TP-3). Washington, DC: The World Bank.

Casiroli, F. 2009. South American cities: Securing an urban future, chapter The mobility DNA of cities, p. 11. London: Cities Programme, London School of Economics and Political Science.

Cervero, R. 1991. Paratransit in Southeast Asia: A market response to poor roads? Review of Urban \& Regional Development Studies, 3(1):3-27. ISSN 1467-940X. doi: 10.1111/j.1467-940X.1991.tb00076.x. URL http://dx. doi.org/10.1111/j.1467-940X.1991.tb00076.x.

Cervero, R. 1998. The transit metropolis: A global inquiry. Washington, DC: Island Press.

Cervero, R. 2000. Informal transport in the developing world. Nairobi, Kenya: UN Habitat. URL http://www.unhabitat.org/pmss/getElectronicVersion. aspx?nr $=1534 \&$ alt $=1$.

Cervero, R. 2005. Progressive transport and the poor: Bogotás bold steps forward. Access, 27:24-30. URL http://www.uctc.net/access/27/Access\%2027\%20-\% 2005\%20-\%20Progressive\%20Transport\%20and\% 20the\%20Poor.pdf.

Cervero, R. and J. Day. 2008. Suburbanization and transit-oriented development in China. Transport Policy, 15(5):315-323. doi: 10.1016/j.tranpol.2008.12.011.
Cervero, R. and C.D. Kang. 2011. Bus Rapid Transit impacts on land uses and land values in Seoul, Korea. Transport Policy, 18(1):102-116. ISSN 0967070X. doi: 10.1016/j.tranpol.2010.06.005. URL http://www.sciencedirect.com/science/article/pii/ S0967070X1000082X.

Cervero, R. and J. Landis. 1997. Twenty years of the Bay Area Rapid Transit system: Land use and development impacts. Transportation Research Part A: Policy and Practice, 31(4):309-333. ISSN 0965-8564. doi: 10.1016/S09658564(96)00027-4. URL http://www.sciencedirect.com/ science/article/pii/S0965856496000274.

Cervero, R., O. L. Sarmiento, E. Jacoby, L. F. Gomez, and A. Neiman. 2009. Influences of built environments on walking and cycling: Lessons from Bogota. International Journal of Sustainable Transportation, 3(4):203-226. doi: 10.1080/15568310802178314. http://www.tandfonline.com/doi/pdf/10.1080/

15568310802178314, URL http://www.tandfonline. com/doi/abs/10.1080/15568310802178314.

Cervero, R. and S. Seskin. 1995. An evaluation of the relationship between transit and urban form. Technical Report Research Results Digest 7, Transit Cooperative Research Program, National Research Council, Washington, DC. URL http://onlinepubs.trb.org/onlinepubs/tcrp/ tcrp_rrd_07.pdf.

Chin, H. 2011. Sustainable urban mobility in south-eastern Asia and the Pacific. Technical report, UN Habitat, Nairobi, Kenya. URL http://www.unhabitat.org/grhs/ 2013.

Davis, L. and M. Kahn. 2011. Cash for clunkers? The environmental impact of Mexico's demand for used vehicles. Access, 38:15-21. URL http://www.uctc.net/access/38/ access38_cash_clunkers.pdf.

Day, J. and R. Cervero. 2010. Effects of residential relocation on household and commuting expenditures in Shanghai, China. International Journal of Urban and Regional Research, 34(4):762-788. ISSN 1468-2427. doi: 10.1111/j.1468-2427.2010.00916.x. URL http://dx.doi. org/10.1111/j.1468-2427.2010.00916.x.

Dimitriou, H. 2011. Urban transport in the developing world: $A$ handbook of policy and practice, chapter Transport and city development: Understanding the fundamentals, pp. 8-39. Cheltenham, UK: Edward Elgar.

Duarte, F. and C. Ultramari. 2012. Making public transport and housing match: Accomplishments and failures of Curitba's BRT. Journal of Urban Planning and Development, 138(2):183-194. doi: 10.1061/(ASCE)UP.1943- 
5444.0000107.

Estupiñán, N. and D. A. Rodríguez. 2008. The relationship between urban form and station boardings for Bogotás BRT. Transportation Research Part A: Policy and Practice, 42(2):296-306. ISSN 0965-8564. doi: 10.1016/j.tra.2007.10.006. URL http://www.sciencedirect.com/science/article/pii/ S0965856407000870.

European Commission. 2011. Roadmap to a single European transport area: Towards a competitive and resource efficient transport system. Technical report, European Commission, European Partnership for Transport, Brussels.

Ewing, R. and R. Cervero. 2010. Travel and the built environment. Journal of the American Planning Association, 76(3):265-294. doi: 10.1080/01944361003766766. http://www.tandfonline.com/doi/pdf/10.1080/

01944361003766766, URL http://www.tandfonline. com/doi/abs/10.1080/01944361003766766.

Ferrarazzo, A. and M. Arauz. 2000. Pobreza y transporte: Consultación con grupos de foco en Buenos Aires. Technical report, The World Bank, Informe Final, WB UTS Review, Washington, DC.

Figueroa, O. 1990. Santiago metro: Integration and public transport. In Rail Mass Transit for Developing Countries. Institution of Civil Engineers, London: Thomas Telford.

Gakenheimer, R. 2011. Urban transport in the developing world: A handbook of policy and practice, chapter Land use and transport in rapidly motorizing cities: Contexts of controversy, pp. 40-68. Cheltenham, UK: Edward Elgar.

Gakenheimer, R. and J. Yang. 2006. Land use and access in the Chinese city. Paper prepared for the flagship series on transport, energy, and environment in China, Energy Foundation, San Francisco, CA.

Godard, X. 2011. Sustainable urban mobility in Francophone Sub-Saharan africa. Technical report, UN Habitat, Nairobi, Kenya. URL http://www.unhabitat.org/grhs/ 2013.

Gwilliam, K. 2002. Cities on the move: A World Bank urban transport strategy review. Technical report, World Bank, Washington, DC. URL http://siteresources.worldbank. org/INTURBANTRANSPORT/Resources/cities_on_ the_move.pdf.

Huang, H. 1996. The land-use impacts of urban rail transit systems. Journal of Planning Literature, 11(1):17-30. doi: 10.1177/088541229601100103. http://jpl.sagepub.com/ content/11/1/17.full.pdf+html, URL http://jpl.sagepub. com/content/11/1/17.abstract.
IBM Corporation. 2010. The globalization of traffic congestion: IBM 2010 commuter pain survey. Technical report, IBM Corporation, Armonk, New York.

Infonavit. 2011. Plan financiero, 2011-2015. Technical report, Infonavit, Mexico City.

Ingram, G. and Z. Liu. 1999. Essays in transportation economics and policy, chapter Determinants of motorization and road provision, pp. 325-256. Washington, DC: Brookings Institute.

Jacobs, J. 1961. The death and life of great American cities. New York: Random House.

Jain, A. 2011. Sustainable urban mobility in southern Asia. Technical report, UN Habitat, Nairobi, Kenya. URL http: //www.unhabitat.org/grhs/2013.

Jiron, P. 2011. Sustainable urban mobility in Latin America and the Caribbean. Technical report, UN Habitat, Nairobi, Kenya. URL http://www.unhabitat.org/grhs/2013.

Joshi-Ghani, A. and E. Glaeser. 2013. Rethinking cities, chapter Overview. Washington, DC: The World Bank.

Kaltheier, R. 2002. Urban transport and poverty in developing countries: Analysis and options for transport policy and planning. Eschborn, Germany: Deutsche Gesellschaft für Technische Zusammenarbeit (GTZ) GmbH.

Knight, R. L. and L. L. Trygg. 1977. Evidence of land use impacts of rapid transit systems. Transportation, 6:231247. ISSN 0049-4488. doi: 10.1007/BF00177453. URL http://dx.doi.org/10.1007/BF00177453.

Kotkin, J. 2010. In pictures: The next decade's fastest-growing cities. URL http://www.forbes.com/2010/10/07/ cities-china-chicago-opinions-columnists-joel-kotkin slide 4.htm.

Kutzbach, M. 2010. Megacities and mega traffic. Access, 37:31-35. URL http://www.uctc.net/access/37/ access37_megacities_traffic.pdf.

Levinson, H., S. Zimmerman, J. Clinger, and C. Rutherford. 2002. Bus rapid transit, volume 1: Case studies in Bus Rapid Transit. Technical Report TCRP Report 90, Transit Cooperative Research Program, Washington, DC. URL http://onlinepubs.trb.org/onlinepubs/tcrp/ tcrp_rpt_90v1.pdf.

Li, S.-M. 2003. Housing tenure and residential mobility in urban China: A study of commodity housing development in Beijing and Guangzhou. Urban Affairs Review, 38(4):510534. doi: 10.1177/1078087402250360. http:// uar.sagepub.com/content/38/4/510.full.pdf+html, URL http://uar.sagepub.com/content/38/4/510.abstract.

Li, S.-M. and Y.-M. Siu. 2001. Residential mobility and urban restructuring under market transition: A study 
of Guangzhou, China. The Professional Geographer, 53(2):219-229. ISSN 1467-9272. doi: 10.1111/00330124.00281. URL http://dx.doi.org/10.1111/0033-0124. 00281.

Lin, J. and A. Yang. 2009. Structural analysis of how urban form impacts travel demand: Evidence from Taipei. Urban Studies, 46(9):1951-1967.

Meleis, A. 2011. Women's health and the world's cities, chapter Introduction: Developing urban areas as if gender matters. Philadelphia, PA: University of Pennsylvania Press.

Munoz-Raskin, R. 2010. Walking accessibility to Bus Rapid Transit: Does it affect property values? The case of Bogotá, Colombia. Transport Policy, 17(2):72-84. ISSN 0967-070X. doi: 10.1016/j.tranpol.2009.11.002. URL http://www.sciencedirect.com/science/article/pii/ S0967070X09001334.

Organisation Internationale des Constructeurs d'Automobiles. 2012. Production statistics. URL http://oica.net/category/production-statistics/.

Pan, H., W. Liu, K. Yan, M. Xu, S. Ye, and P. Wei. 2011. Sustainable urban mobility in eastern Asia. Technical report, UN Habitat, Nairobi, Kenya. URL http://www.unhabitat. org/grhs/2013.

Pan, H., Q. Shen, and M. Zhang. 2009. Influence of urban form on travel behaviour in four neighbourhoods of Shanghai. Urban Studies, 46(2):275-294. doi: 10.1177/0042098008099355.

Papagiannakis, A. and E. Masad. 2011. Pavement design and materials. Hoboken, NJ: Wiley \& Sons.

Peñalosa, E. 2002. Urban transport and urban development: A different model. URL http://clas.berkeley.edu/Events/ spring2002/04-08-02-penalosa/index.html.

Pendakur, V. 2005. Non-motorized transport in African cities: Lessons from experience in Kenya and Tanzania. SSATP working paper no. 80, World Bank, Sub-Saharan Africa Transport Policy Program, Washington, DC.

Pirie, G. 2011. Sustainable urban mobility in 'Anglophone' Sub-Saharan Africa. Technical report, UN Habitat, Nairobi, Kenya. URL http://www.unhabitat.org/grhs/ 2013.

Pourbaix, J. 2011. Towards a smart future for cities: Urban transport scenarios for 2025. Public Transport International, 60(3):8-10.

Pucher, J., N. Korattyswaropam, N. Mittal, and N. Ittyerah. 2005. Urban transport crisis in india. Transport Policy, 12:185-198. doi: 10.1016/j.tranpol.2005.02.008.

Rodríguez, D. A., E. M. Brisson, and N. Estupiñán. 2009. The relationship between segment-level built environment attributes and pedestrian activity around Bogota's BRT stations. Transportation Research Part D: Transport and Environment, 14(7):470-478. ISSN 1361-9209. doi: 10.1016/j.trd.2009.06.001. URL http://www.sciencedirect.com/science/article/pii/ S136192090900087X.

Rodríguez, D. A. and C. H. Mojica. 2009. Capitalization of BRT network expansions effects into prices of non-expansion areas. Transportation Research Part A: Policy and Practice, 43(5):560-571. ISSN 0965-8564. doi: 10.1016/j.tra.2009.02.003. URL http://www.sciencedirect.com/science/article/pii/ S0965856409000299.

Rodríguez, D. A. and F. Targa. 2004. Value of accessibility to Bogotás Bus Rapid Transit system. Transport Reviews, 24(5):587-610. doi: 10.1080/0144164042000195081. http://www.tandfonline.com/doi/pdf/10.1080/

0144164042000195081, URL http://www.tandfonline. com/doi/abs/10.1080/0144164042000195081.

Santos, E. 2011. Pioneer in BRT and urban planning. Saarbrücken, Germany: Lambert Academic Press.

Sperling, D. and D. Gordon. 2009. Two billion cars: Driving toward sustainability. Oxford: Oxford University Press.

Suzuki, H., R. Cervero, and K. Iuchi. 2013. Transforming cities with transit: Transit and land-use integration for sustainable urban development. Technical report, The World Bank, Washington, DC.

Suzuki, H., A. Dastur, S. Moffatt, N. Yabuki, and H. Maryyama. 2010. Eco2 cities: Ecological cities as economic cities. Washington, DC: World Bank.

Swamy, H., S. Sinha, N. Bhakuni, and S. Imchen. 2012. Integrated spatial development: Summary reportAhmedabad. Technical report, Centre of Excellence in Urban Transport, CEPT University, Ahmedabad, India.

Tarazona, H. 2008. Portales de transmilenio: Revitalización de espacios e integración social urbana. Technical report, Ediciones Uniandes, Bogotá.

Tiwari, G. 2011. Key mobility challenges in indian cities. Discussion paper 2011-18, Organization for Economic Development/International Transport Forum, Paris.

UITP (International Association of Public Transport). 2011. Report on statistical indicators of public transport performance in Africa. Technical Report Version 1.3, UITP, Brussels.

United Nations. 2011. The millennium development goals report 2011. Technical report, United Nations, New York.

United Nations Habitat. 2011. Global report on human settlements 2011: Cities and climate change. Technical report, 
UN Habitat, London.

Vasconcellos, E. 2001. Urban transport, environment and equity: The case for developing countries. London: Earthscan.

World Bank. 2009. World development report: Reshaping economic geography. Technical report, The World Bank, Washington, DC.

World Bank. 2010. World development indicators 2010. Technical report, The World Bank, Washington, DC.

World Bank. 2011. World development indicators 2011. Technical report, The World Bank, Washington, DC.

World Economic Forum. 2012. Caracas, Venezuela: Neighborhood Upgrading. Urban Anthologies: Learning from our Cities. New York: World Economic Forum.

Yang, J., Q. Shen, J. Shen, and C. He. 2012. Transport impacts of clustered development in Beijing: Compact development versus overconcentration. Urban Studies, 49(6):1315-1331. doi: 10.1177/0042098011410336. http://usj.sagepub. com/content/49/6/1315.full.pdf+html, URL http://usj.sagepub.com/content/49/6/1315.abstract.

Zegras, C. 2010. The built environment and motor vehicle ownership and use: Evidence from Santiago de Chile. Urban Studies, 47(8):1793-1817. doi: 10.1177/0042098009356125. http://usj.sagepub. com/content/47/8/1793.full.pdf+html, URL http://usj. sagepub.com/content/47/8/1793.abstract.

Zegras, C. P. 2004. Influence of land use on travel behavior in Santiago, Chile. Transportation Research Record: Journal of the Transportation Research Board, 1898(1):175-182. doi: 10.3141/1898-21. URL http://trb.metapress.com/ content/R6U34VQ1M2446145.

Zegras, C. P. 2012. Dynamics of automobile ownership under rapid growth. Transportation Research Record: Journal of the Transportation Research Board, 2323(1):80-89. doi: 10.3141/2323-10. URL http://trb.metapress.com/ content/7657167548H4K611.

Zhang, M. 2004. The role of land use in travel mode choice: Evidence from Boston and Hong Kong. Journal of the American Planning Association, 70(3):344-360. doi: 10.1080/01944360408976383. http://www.tandfonline. com/doi/pdf/10.1080/01944360408976383, URL http://www.tandfonline.com/doi/abs/10.1080/ 01944360408976383.

Zhao, P. 2011. Car use, commuting and urban form in a rapidly growing city: Evidence from Beijing. Transportation Planning and Technology, 34(6):509527. doi: 10.1080/03081060.2011.600049. http://www.tandfonline.com/doi/pdf/10.1080/
03081060.2011.600049, URL http://www.tandfonline. com/doi/abs/10.1080/03081060.2011.600049. 